Paedagogia Christiana

I/27 (201 I) - ISSN 1505-6872

\title{
Kazimierz Misiaszek, Koncepcja nauczania religii katolickiej w pu- blicznej szkole polskiej. Próba oceny, Wydawnictwo Towarzystwa Naukowego Franciszka Salezego, Warszawa 2010, ss. 322.
}

Ks. Kazimierz Misiaszek SDB to jeden z naszych najbardziej znanych i wysoko cenionych katechetyków średniego pokolenia. Niegdyś uczeń ks. prof. M. Majewskiego SDB, potem wieloletni, bliski współpracownik ks. prof. R. Murawskiego SDB, dziś kierownik Sekcji Katechetyki oraz Katedry Dydaktyki Katechetycznej na Wydziale Teologicznym UKSW.

Mamy jeszcze w pamięci cenną książkę ks. K. Misiaszka - jego rozprawę habilitacyjną - o nauczaniu religii w dzisiejszej szkole włoskiej: Koncepcja nauczania religii katolickiej w publicznej szkole włoskiej po Konkordacie z 1984 r. Próba oceny (Warszawa 1999). To rzecz sprzed lat. Chciałoby się zapytać, co było potem. Jak się okazuje, nasz badacz nie stanął w miejscu. Znalazł bardzo atrakcyjne pola naukowych eksploracji. Takie, dzięki którym mógł wnieść do polskiej katechetyki wiele nowego. W toku swych badań pytał między innymi o adresatów przekazu katechetycznego, o kontekst tego przekazu, a wreszcie o kształt przekazu. Jednak stawiając owe pytania, nie chciał usłyszeć wszystkich możliwych odpowiedzi. Wybrał jedynie te, które uznał za ważne i dla aktualnej debaty w środowisku katechetyków potrzebne. Przyglądając się adresatom katechezy, zatrzymał się na katechezie dorosłych. Interesując się kontekstem przekazu, dotknął generaliów - fenomenu kultury. Pytanie o kształt przekazu skonkretyzował w pytaniu o język w katechezie. Owszem, nie są to zagadnienia dopiero odkryte przez ks. K. Misiaszka; jednakże to, co pokazał owe zagadnienia podejmując, daje mu status niekonwencjonalnego i wytrawnego badacza.

Zatrzymajmy się krótko przy tych zagadnieniach. Zagadnienie pierwsze to katecheza dorosłych. Ks. K. Misiaszka interesuje sama koncepcja tej katechezy, jej charakterystyczne rysy i wielorakie uwarunkowania. Za 
Janem Pawłem II widzi katechezę dorosłych jako uprzywilejowaną postać katechezy. To od niej w posłudze Kościoła wypada rozpoczynać i na niej opierać inne rodzaje katechezy. Wszak pierwszymi katechetami winni być dla swych dzieci rodzice. Stąd pilna potrzeba budowania rozwiązań organizacyjnych - także w warunkach polskich - adekwatnych do tego rodzaju zadań. Ks. K. Misiaszek nie tylko obserwuje naszą katechezę dorosłych, ale i buduje jej koncepcję. Robi to, sięgając - ze wszech miar słusznie - do dorobku psychologii i pedagogiki. Rozumie, że równie istotne, jak rozpoznanie treści katechetycznego przekazu, musi być poznanie jego adresatów. Katechezy dorosłych dotyczy szereg poważnych publikacji ks. K. Misiaszka, w tym dwie książki pod jego redakcją: Katecheza dorostych we wspólnocie Kościoła (Warszawa 2002) i Katecheza dorostych (Tarnów 2009, współredaktor ks. J. Stala). Także sporo artykułów.

Zagadnienie drugie to kultura. Jak się okazuje, jest ona dla ks. K. Misiaszka niezmiernie istotnym faktorem dociekań katechetycznych. Na tezę, że wszelka katecheza musi funkcjonować w określonej szacie kulturowej, wśród katechetyków i katechetów uzyskalibyśmy zgodę powszechną. Za taką deklaracją musi iść poważny wysiłek katechizującego Kościoła, o ile naprawdę zależy mu na inkulturacji wiary. Także w tym miejscu ks. K. Misiaszek idzie za przekonaniem Jana Pawła II, że wiara winna stawać się kulturą. Gdy nią nie jest, nie ma szans stać się w pełni skuteczną. Przy tym fundamentalnym założeniu otwiera się przed katechetyką szerokie pole dla debaty o związkach między katechezą i kulturą. Ks. K. Misiaszek śmiało wchodzi na to pole i porusza się po nim swobodnie, budując swój projekt katechezy inkulturowej.

Z owym projektem katechezy inkulturowej wiąże się ściśle trzecie ze wskazanych zagadnień: język w katechezie i w szkolnym nauczaniu religii. To zrozumiałe, wszak język - jako system komunikacji międzyludzkiej jest podstawowym fenomenem kultury. Ks. K. Misiaszek trafnie konstatuje dzisiejsze trudności w komunikacji między wychowawcami i wychowankami; nawet szerzej - między starszym i młodszym pokoleniem. Stąd zasadne pytanie o współczesny język katechezy i szerzej: o współczesny język religijny. Pytanie o język adekwatny zarówno do przekazywanych w katechezie treści, jak i do wrażliwości ich adresata. Znana dobrze zasada katechezy wiernej Bogu i człowiekowi znajduje tu przełożenie na konkret katechetycznej posługi Kościoła. Ks. K. Misiaszek z odwagą wchodzi we wskazaną tu problematykę. Nie rości sobie jednak - i słusznie - pretensji bycia językoznawcą. Pozostaje na właściwym sobie terenie. Zatroskany o wychowawczą skuteczność katechezy czy nauczania religii, usilnie zachęca katechetów i nauczycieli religii do współpracy z ekspertami od języka religijnego. To misja ważna i potrzebna. 
Owe trzy obszary badań ks. K. Misiaszka nie wyczerpują jego zainteresowań. Jak mało który z polskich katechetyków wyraźnie odróżnia szkolne nauczanie religii od katechezy. I słusznie. To rozróżnienie nakłada wszak na naszego badacza obowiązek odrębnej debaty nad tymi dwoma obszarami edukacyjnej i wychowawczej pracy Kościoła. Od lat pilnie obserwuje to, co dzieje się w polskiej szkole. Szkolne nauczanie religii ogląda w szkolnej i konfesyjnej perspektywie. Akcentuje niedostatki edukacyjnych założeń programowych szkolnych lekcji religii. W debacie o katechezie dzieci i młodzieży akcentuje potrzebę inkulturacyjnego ukierunkowania katechezy. Od dobrej katechezy oczekuje uwzględnienia wszystkich czynników wychowania. Katecheza bowiem nie może się odbywać ani wbrew, ani nawet obok wychowania. Z drugiej strony, nie może być redukowana wyłącznie do wychowania. Proces formacji religijnej - akcentuje ks. K. Misiaszek - musi bowiem uwzględniać specyfikę religii.

Z przynależnością do zgromadzenia salezjańskiego wiążą się, co oczywiste, zainteresowania badawcze ks. K. Misiaszka metodą wychowawczą św. Jana Bosko. Nie miejsce tu na charakterystykę jego systemu prewencyjnego. Trudno wszak nie zaakcentować, że w ks. K. Misiaszku system św. Jana Bosko znajduje atrakcyjnego komentatora. Ks. K. Misiaszek, idąc za oczekiwaniem swego Ojca Założyciela, że w dobrym wychowaniu będą się łączyć rozum, religia i miłość wychowawcza, uwydatnia postawienie przez św. Jana Bosko rozumu na pierwszym miejscu. Nie jest to - wedle ks. K. Misiaszka - przypadkowe. Bowiem wychowanie ma być najpierw i przede wszystkim rozumne. Właśnie takie domaga się dopełnienia wartościami religijnymi oraz zintegrowania z nimi tym wychowawczo fundamentalnym czynnikiem, jakim jest miłość.

To w kontekście takich zainteresowań i kompetencji autora dostajemy opublikowana przez Towarzystwo Naukowe Franciszka Salezego w serii „Studia i Rozprawy” książkę o tytule: Koncepcja nauczania religii katolickiej w publicznej szkole polskiej. Próba oceny. Ta, powiedzmy od razu, świetną książką autor wchodzi wyraziście w samo sedno od lat dwudziestu toczonych u nas dyskusji na temat tożsamości aktualnego modelu obecności Kościoła katolickiego w polskiej szkole. Nie feruje wyroków, nie rozdziela razów (choć chwilami czujemy, że miałby ku temu powody i narzędzia), ale spokojnie i metodycznie rozpracowuje dokumenty kościelne, pokazuje opinie naszych katechetyków, a zwłaszcza dydaktyczno-wychowawcze realia polskiej szkoły. Daje poważny głos w dyskusji na temat wyznaniowego, bezwyznaniowego i ponadwyznaniowego nauczania religii w szkole.

Sprawą kluczową, poniekąd osią organizującą całość dociekań, jest rozróżnienie lekcji religii i katechezy. To kwestia dla książki istotna, choć - co ciekawe - w żadnym z tytułów rozdziałów lub podrozdziałów nie pojawia 
się termin „katecheza”. Otóż odwołując się do nauczania Kościoła, nasz autor akcentuje, że

nauczanie religii w szkole nie było, nie jest i nie może być traktowane na równi z katechezą parafialną. To ona, właśnie katecheza, jest wciąż pierwszorzędnym zadaniem Kościoła, i to ona powinna być, dla zintegrowania wszystkich działań wychowawczych Kościoła, uzupełniana innymi formami katechetycznymi, wśród których znajduje się - w sensie szerokim - także nauczanie religii w szkole. Kwestia ta posiada szczególne znaczenie głównie w odniesieniu do wymiaru wtajemniczenia, fundamentalnego dla rozwoju wiary i życia chrześcijańskiego (s. 220n).

Owszem, Jan Paweł II uznawał katechezę za najważniejsze zadanie dla Kościoła (CT n. 15) i w swej adhortacji o katechizacji nie podejmował tematu szkolnych lekcji religii. Trudno sobie nawet wyobrazić, by takie lekcje w szkole publicznej mógł także uznać za najważniejsze zadanie dla Kościoła. I to przy całym - powszechnie znanym - szacunku Papieża dla instytucji szkoły.

Dyrektorium o katechizacji z 1997 r. pójdzie znacznie dalej niż Catechesi tradendae, rozróżniając katechezę i lekcje religii. Ks. K. Misiaszek podąża za tym rozróżnieniem, nie do końca respektowanym przez wielu katechetyków, co pozwala mu zdystansować się od traktowania szkolnych lekcji religii jako podstawowej dziś formy pracy katechetycznej Kościoła w Polsce. I słusznie. Dyrektorium Kościoła powszechnego zaznacza bowiem, iż „katecheza jest ze swej istoty aktem eklezjalnym” (n. 78). Natomiast pluralistyczna w swym charakterze szkoła - także polska szkoła - nie jest Kościołem i nie może tworzyć Kościoła. Stąd i nie spełnia warunków, by być podmiotem katechezy. Obecna w polskiej szkole lekcja religii, akcentuje ks. K. Misiaszek, może uczyć o Kościele, ale „nie jest w stanie budować w szkole Kościoła" (s. 224).

Prawdą jest przy tym, że organizator lekcji religii w szkole, zwłaszcza merytorycznego kształtu tych zajęć, to jest Kościół, wśród celów obecności nauczania religii w szkole akcentuje właściwe dla siebie cele, które autor nazywa wprost kościelnymi. Nie są one - co oczywiste - celami samej szkoły. Cele Kościoła to ewangelizacja i katechizacja. Katecheza w pełnym jej rozumieniu, a tym bardziej ewangelizacja, okazują się niemożliwe do realizacji w szkole mającej przecież własne cele, zadania, także metody pracy. Jeśli dziś mówi się o nowej ewangelizacji, to w odniesieniu do szkoły może co najwyżej chodzić o nowy zapał w prowadzeniu lekcji religii, o poszukiwanie nowych metod dydaktycznych, a nie o ściśle rozumianą ewangelizację środowiska szkolnego, które przecież ma być środowiskiem kształtowania po- 
staw tolerancji. Dokument Kongregacji Wychowania Katolickiego Religijny wymiar wychowania w szkole katolickiej zgłasza wątpliwości co do możności prowadzenia katechezy nawet na terenie takiej szkoły. Tym bardziej wątpliwości tego rodzaju wolno odnosić do szkoły publicznej w podlegającym wpływom laicyzacyjnym społeczeństwie.

Nie znajdując miejsca na ewangelizacyjną posługę Kościoła w ramach szkolnych zajęć z religii, ks. K. Misiaszek chce ją usytuować w środowiskach pozaszkolnych, szczególnie w parafiach, ale także w ,szeroko rozumianych wspólnotach życia chrześcijańskiego, ruchach czy stowarzyszeniach katolickich” (s. 209). O ile ze wskazaniem parafii wypada się zgodzić, to mówienie w kontekście ewangelizacji o wspólnotach i ruchach może budzić watpliwości recenzenta. Wszak są to środowiska eklezjalne, których uczestnicy własną ewangelizację mają już za sobą. Właśnie jako skutecznie zewangelizowani są w stanie uczestniczyć w działalności wspólnot, ruchów, stowarzyszeń.

Autor trafnie akcentuje oczywisty dysonans między celami ewangelizacyjnej i katechetycznej misji Kościoła a celami dydaktyczno-wychowawczymi szkoły. Dysonans ów implikuje pewne trudności z obecnością religii w szkole. Staje pytanie o środki terapeutyczne. Ks. Kazimierz Misiaszek chce je znaleźć - mówiąc najkrócej - w większym niż dotąd liczeniu się nauczyciela religii z realiami własnego środowiska szkolnego. Postuluje oprzeć obecność religii w szkole na tym, co wspólne tak celom lekcji religii, jak i celom szkoły. Są to zadania kształcenia i wychowania. W ich perspektywie spotkanie Kościoła i szkoły jest równie potrzebne, co możliwe. Konieczne jest zatem najpierw i przede wszystkim zainteresowanie się nauczyciela religii szkoła, w której pracuje; jej problemami, jej historią, jej etosem. W takim kontekście budowanie roli wychowawczej szkolnych zajęć z religii we współpracy z programem wychowawczym szkoły oraz budowanie roli edukacyjnej tych zajęć we współpracy z treściami programowymi wielu przedmiotów. „Potrzebna byłaby jednak rezygnacja z twierdzenia, że szkoła jest dla Kościoła jedynie miejscem realizacji jego własnych celów, a więc misyjnych i duszpasterskich, które nie zawsze są utożsamiane przez uczniów, nauczycieli i rodziców z celami edukacji w szkole” (s. 257).

To na fundamencie wychowawczych i edukacyjnych celów szkoły chce ks. K. Misiaszek usytuować współpracę Kościoła ze szkołą. „Przecież Kościół posiada swoją pedagogię wiary, na gruncie której mogłoby dojść do dialogu z pedagogią szkolną, doprowadzając do ich wzajemnego uzupełniania i ubogacania" (s. 255). Właśnie pojęcie dialogu wydaje się u naszego autora ważne. To nie dziwi. Bowiem z dialogicznej struktury Kościoła, odwołującej się do dialogu zbawienia, wypływa konieczność dialogicznego sposobu jego funkcjonowania wśród ludzi i społecznych struktur. Także w szkole. Jednak ów dialog Kościoła i szkoły nie musi być ani łatwy, ani bezkonfliktowy. 
Trudności - bardziej o aksjologicznym niż organizacyjnych charakterze mogą się pojawiać i faktycznie się pojawiają po obu stronach.

Pojawia się także pytanie o optymalną płaszczyznę postulowanego przez autora dialogu; przestrzeń spotkania Kościoła i szkoły. Niech nią będzie - wskazuje ks. K. Misiaszek - kultura. Szkoła bowiem ,jest ze swej natury instytucją wprowadzającą w kulturę, a Kościół jest zainteresowany integracją wiary i kultury" (s. 277). Obecność religii w szkole ma powszechnie znane tradycje. Wynika, podkreśla to ks. K. Misiaszek, nie tyle z założeń konfesyjnych, ile „z racji kulturowych, edukacyjnych i wychowawczych” (s. 279). Dla pełnego i integralnego charakteru szkoły obecne w niej kształcenie i wychowanie nie może ignorować faktu religii, konstytutywnego przecież dla zjawiska kultury. Szkoła, wprowadzająca młodego człowieka w świat europejskiej i polskiej kultury, musi zatem wprowadzać go zarazem w chrześcijaństwo. Dziś nie jest to u nas proste wobec braku jednoznacznych powiązań oferty aksjologicznej wielu szkół, często zdominowanej przez liberalne opcje moralne, z propozycjami Kościoła.

Posługa Kościoła w szkole powinna zatem, zdaniem ks. K. Misiaszka, liczyć się z charakterem tej ostatniej. Misja Kościoła w szkole nie zmieni szkoły, o ile Kościół nie wejdzie z nią w poważny dialog wychowawczy. Stąd propozycja, by ,szkoła była bardziej obecna w programowaniu lekcji religii” (s. 277). Obecność religii w szkole winna być oparta na tym, co wspólne tak celom lekcji religii, jak celom szkoły. Są to zadania kształcenia i wychowania. $\mathrm{W}$ ich perspektywie spotkanie Kościoła i szkoły jest równie potrzebne, co możliwe.

Powyższe konstatacje i wnioski sytuują się w merytorycznym centrum rozprawy ks. Kazimierza Misiaszka. Nie wyczerpują jej jednak. Są pomieszczone w dwóch końcowych rozdziałach studium, pokazujących charakter nauczania religii w szkole oraz cele i zadania tego nauczania. Trzy wcześniejsze rozdziały - a każdy z nich o niekwestionowanych walorach merytorycznych - przygotowują i czynią prawomocnym to, o czym wyżej. Rozdział pierwszy przeznacza autor na pokazanie nauczania religii w szkole publicznej w różnych krajach europejskich. Jednakże nie wyodrębnia charakterystyki sytuacji w poszczególnych krajach, ale daje ujęcie problemowe. Omawia status prawny lekcji religii, status prawny nauczycieli religii i sposoby ich kształcenia, nauczanie religii dla mniejszości religijnych itd. Po niezmiernie bogatym materiale empirycznym porusza się z dużą zręcznością. Dokumentuje swe zdolności analityczne, ale i sprawność w konstruowaniu syntez. Rozdział drugi stanowi zarys historii polskiego nauczania religii w szkole - w czasach II Rzeczypospolitej i w PRL-u. Na dalszych 50 stronach, już w rozdziale trzecim, autor pokazuje to, co z nauczaniem religii działo się $\mathrm{w}$ minionym dwudziestoleciu. Oglądamy powrót nauczania religii do szkoły w 1990 r. oraz 
społeczne debaty wokół tego powrotu i ich - jak określa autor - historyczną weryfikację. Z niekwestionowaną kompetencją, a i z dużą swobodą, wędruje ks. K. Misiaszek po tym materiale z najnowszej historii Polski. Z dociekliwością i znawstwem analizuje zmieniające się z biegiem lat, a precyzyjnie przez siebie przywoływane, regulacje prawne określające usytuowanie nauczania religii w szkole. To niezmiernie cenne fragmenty studium.

Summa summarum książka świetna, merytorycznie i formalnie dojrzała. Bardzo ważna dla debaty o tym, co się dzieje, co może i co powinno się dziać w polskiej szkole w perspektywie obecności tam nauczania religii. Lektura obowiązkowa dla każdego ambitnego, w tym zwłaszcza świadomego swych zadań katechety.

Andrzej Potocki*

\section{Grzegorz Grzybek, Etyka rozwoju a wychowanie, Wydawnictwo Uniwersytetu Rzeszowskiego, Rzeszów 2010, ss. 160.}

Problematyka filozofii wychowania oraz moralnych aspektów edukacji od lat stanowi przedmiot nieustających dyskusji i polemik naukowych. Oficyna wydawnicza Uniwersytetu Rzeszowskiego włączyła się także do toczącego się dyskursu, wydając książkę Grzegorza Grzybka Etyka rozwoju a wychowanie. W publikacji tej autor zmierzył się z jednym z najważniejszych problemów dotyczących przebiegu procesu wychowania, jakim jest kwestia uchwycenia prawidłowości rozwoju moralnego nie tylko wychowanka, ale także osób odpowiedzialnych za przebieg procesów tego typu. Przy takim ujęciu proces ten przestaje być jednostronnym przekazem informacji, a staje się harmonijnym współgraniem wszystkich elementów uczestniczących w jego przebiegu. Można przy tej okazji zauważyć, że autor dokonuje próby przeanalizowania problematyki wychowawczej z wykorzystaniem całego dorobku antropologii filozoficznej.

$\mathrm{Na}$ całość opracowania składa się poprzedzonych wstępem sześć rozdziałów zebranych w dwóch częściach, z których pierwsza obejmuje zagadnienia aksjologii wychowania, a druga obejmuje przedstawienie wyników przeprowadzonych badań empirycznych oraz ich analizę w kontekście usprawnienia procesów edukacyjnych. Publikację dopełnia zakończenie, postscriptum i bibliografia.

* Prof. dr hab. Andrzej Potocki OP - socjolog i teolog; pracuje w Instytucie Profilaktyki Społecznej i Resocjalizacji Uniwersytetu Warszawskiego, w Instytucie Filozofii i Socjologii Akademii Pedagogiki Specjalnej im. M. Grzegorzewskiej w Warszawie, w Kolegium Filozoficzno-Teologicznym OO. Dominikanów w Krakowie. 